\title{
EMBRACING THE FUTURE OF ENGINEERING EDUCATION IN NIGERIA: TEACHING AND LEARNING CHALLENGES
}

\author{
A. A. Oloyede ${ }^{1,}{ }^{*}$, H. A. Ajimotokan ${ }^{2}$ and N. Faruk ${ }^{3}$ \\ 1,3 DEPARTMENT OF TEleCOMMUNiCATION SCIENCE, UNIVERSITY OF ILORIN, ILORIN, KWARA STATE, NIGERIA. \\ 2DEPARTMENT OF MECHANICAL ENGINEERING, UNIVERSITY OF ILORIN, ILORIN, KWARA STATE, NIGERIA \\ Email addresses: ${ }^{1}$ oloyede.aa@unilorin.edu.ng, ${ }^{2}$ haajins@yahoo.com, ${ }^{3}$ faruk.n@unilorin.edu.ng
}

\begin{abstract}
There has been a wide advocacy around the adoption of better teaching methods for Engineering Education in Nigeria, more especially with the advent of information and telecommunication technologies. However, compared with what was applicable, about 40 to 50 years ago, little has changed in the country in relation to classroom teaching and learning, use of teaching aids, and laboratory works among others. The general concept of the Nigerian education system and the role of engineering in the educational system are examined in this paper. It also examines the present Nigerian engineering teaching style and outputs, some of the challenges being faced by engineering education in Nigeria especially in relation to teaching and learning highlighted. The work proposes some changes that would make engineering education better in Nigeria while showing that sustainable engineering education development for the future engineering education lies in a modified teaching-learning approach guided by real-world problems.
\end{abstract}

Keywords: engineering education, teaching methods, dynamic curriculum, learning challenges

\section{INTRODUCTION}

In Nigeria, a lot of emphases have been on accruing educational certificates from both local and international higher education institutions. According to independent research conducted by Rice University and commissioned by the Chronicle, Nigerian immigrants have the highest levels of education in the Houston area and the wider United States of America, which surpasses the whites and Asians [1]. These shows how important Nigerians all over the world value education. The current Nigeria education structure is based on 9-3-4 system commonly referred to as the Universal Basic Education (UBE) [2]. This has been introduced to replace the old 6-3-3-4 system introduced in 1983. The need for this switch was based on the policy framework and objective envisaged to be achieved by each system. The primary goal of the conventional 6-3-3-4 system was to provide educational needs of citizenry and equipping the youths with sellable skills that will make them to be self-reliant[2]. However, the new 9-3-4 system aimed at developing curriculum that would meet the Millennium Development Goals (MDGs) by 2020.The policy shift has been fully achieved. However, the desired objectives are not achieved that would commensurate with the aim of the switch over. This is as the result of lack of basic facilities such as availability of instructional materials for the teaching of the technology subjects, non-availability of personnel, adequate funding, student-teacher ratio, laboratory or workshop-student ratio, infrastructure, teaching style/methods and many others. These factors would drive the implementation of the policies and sustainable development of the education system. Unlike other countries, the United Kingdom (UK) education system which in 1988, provided a framework for education between the ages of $5-18$. This spans through five stages (i.e. the early years, primary education, secondary education, further education and higher education [3]. The framework didn't account for early years 1-4, but later come into force in The Education Act 2002. The United States education system is into three levels: elementary/primary education, secondary education, and postsecondary/ higher education (college or university) [4]. China for instance runs 6-3-3-2-4 system. The Nigerian education system has an edge over most of the framework adopted globally, as the six years spent on secondary education compared to some other countries with a 5-year secondary education. Engineering education which is majorly taught at the higher institution has become a key aspect of education 
in Nigeria. Engineering education is based on conceptualising, creating and maintaining processes or systems that are needed by humans or the society. This paper shall examine if the present engineering teaching trend is sustainable. This paper shall also examine the current approach to engineering education in Nigeria, the factors behind the observed success, challenges and proffer some solutions and methods to improving engineering education in Nigeria. The present and future of engineering education both at the local and international level are also examined with some recommendations for a sustainable teaching method that would meet the future need of the nation.

The rest of this paper is as follows. Section 2 provides the overview of engineering education in Nigeria. Section 3 is the methodology adopted for this work. The present situation and challenges of the engineering education in Nigeria are presented in Section 4. Section 5 provides the future of engineering education around the globe, and the ideal future of the Nigerian engineering education industry is provided in section 6 while the conclusions are provided in the last section.

\section{OVERVIEW OF ENGINEERING EDUCATION IN NIGERIA}

Engineering education was neglected among other fields of education in Nigeria until around the middle of the $19^{\text {th }}$ century[5]. Nigeria, however, realised that this field is one of the major bedrock of any nation and established a number of Technical Colleges, Polytechnics and Faculty of Engineering in Universities just after the independence of the country [5]. As a result of the importance and technicality of engineering education, the study of any engineering degree in Nigeria is structured for a five-year period, with the first year spent studying general sciences. To become a fully qualified engineer, a graduate of any Engineering degree must practice for a minimum of four years, among other requirements before becoming a registered engineer with the Council for the Regulation of Engineering in Nigeria (COREN).

The Nigerian engineering education performed well by meeting the immediate need of the early postindependence period. The educational performance at that time was also commended, especially giving the fact that most engineering teachers worked with the knowledge of the industry [6]. However, in recent times, the standard of engineering education in Nigeria is of a major concern more especially to the industries as it seems the standard is falling[7].Thus, creating a disconnect between the skills required by the labour markets and what is obtainable by the graduates. This leads to the call for improvement of the existing classical course delivery methods toward meeting the labour market needs. However, over the years, extensive information technology, cutting edge technological ideas and developmental initiative are happening in the world as a result of engineering innovations, however, there are no major changes in the engineering education, lecturing style, and attitude within the same time frame in Nigeria $[8,9]$. Despite these challenges, some Nigerians are still arguing that the system is not as bad because some engineering students are still managing to record some level of success both at home and outside the country, while, working or in pursuit of a higher education. So, are these successes as a result of the old glory? Are we approaching the limits of this glory?

\section{METHODOLOGY AND DATA COLLECTION}

This study adopted an approach based on survey design and data collection. A structured questioner was used to collect data from students and lectures. Each of the lecturers that the questioners where administered on poses at least a degree from outside Nigeria. Students and lecturers are mainly from University of Ilorin, Ilorin and Kwara State University, Malate, Nigeria. The questioner comprises of demographic information and specific questions regarding the received and perceived quality of engineering education in Nigeria and outside Nigeria. In addition to this, data about the numbers and performances of Nigerians who after having an undergraduate education in Nigeria, studied a postgraduate degree in a field of engineering in the UK was also collected. A request was sent to $25 \mathrm{UK}$ based higher institutions, and about 14 of them responded with the information on the number of Nigerians admitted in the engineering department from the year 2000 to date, who passed among those admitted and who graduated with a distinction among other information. All the university that responded provided detailed explanation however they did not provide the details on numbers which involves only 1 or 2 students failed in a class. This was done in order to protect the identity of the students. They argued that such information is against the law. The manner and details collected by some of the Universities that responded are also different. Therefore, only 12 of the 14 set of information from the Universities that responded are used in this paper.

\section{THE PRESENT SITUATION AND THE CHALLENGES FACING ENGINEERING EDUCATION IN NIGERIA.}

There are lots of challenges being faced by engineering education in Nigeria. In [7, 10,11] some challenges ad issues facing the engineering education in Nigeria were discussed. These were outlined as: effective Engineering Education curriculum, inadequate basic 
knowledge by the engineering students, an explosion in enrolled students, difficulties in students recruitments, inadequate facilities for teaching of engineering education, lack off or inadequate university industry linkages, inadequate funding of education, inadequate mentoring of engineering lecturers, lack of special remunerations to engineers, teacher-to-student ratio and the use of ineffective teaching methods. Furthermore, lack of basic infrastructure, lack of necessary support from non-academic staff, poor access to internet services, irregular power supply, lack of good leadership and mentoring schemes are among other challenges identified in[6,12,13]. Jaraiedi and Ritz[8] also pointed out that the system of education in Nigeria today is more of socialising with less emphasis on hard work both on the part of the students and the lecturers. These challenges are having a significant impact on the quality of Education in Nigeria as discussed in the examined literature. However, this paper shall focus mainly on the three areas that have to do with content delivery namely: the curriculum, equipment and the teaching methods used in Engineering Education in Nigeria. In discussing the situation, this paper shall explore some of the present situations and proffer solutions to sustainable engineering education in Nigeria.

\subsection{Teaching and Learning Methods}

Teaching is the process of transferring knowledge. It should be delivered in a systematic, interactive, organized and purposive manner [14]. The primary purpose of teaching at any level is to bring a fundamental change in students' learning [15]. It is therefore, expected that teaching will cause desirable change in the learners' behaviour. Learners in this context, we are referring to the students. Therefore, teaching should be seen as the integral part of any Educational policy framework implementation as it would have a direct impact on the students' learning. There are many teaching methods available, and some of these methods have been tested in diverse environments and proven effective in different scenarios. These include discovery method spaced lecture, group work, dialogue, scaffolding and constructivism etc[16-19]. However, in Nigeria, the most widely used teaching methods are: lecture method, discussion method, project method, simulation method and problem solving method [20-22].The lecture method is also commonly referred to as "talkchalk method" which involves the teacher explaining the ideas with giving examples and occasionally, writes on the chalk board. The project method on the other hand involves active participation of the student in such a way that a cooperative (group) study of a real life situation in the class is undertaken, under the supervision of the teacher. The drama method, may also be classified as group method as it involves a group-oriented approach[14]. However, the concerned, feelings and reactions of the students in this situation are taken into consideration during the course of interacting with one another. This may also be referred to as the "Role-Play Method". Simulation method is a more practical oriented approach of teaching where students are exposed to devices and equipment physically. This method is considered as the most efficient in Science and Engineering related subjects as it's hasten and stimulates the understanding of learners. So many learning methods have been identified and associated with specific teaching methods. In [12], 32 learning methods were identified and these include: visual, auditory, sensing, inductive, active, creative and passive.

Today, in Nigeria, mostly, engineering lecture rooms are faced with a similar scenario as it was in decades ago. The teaching methodology is still the conventional approach where a teacher delivers lectures by standing in the classroom, dictating notes or deriving equations from the 'old' notebook', recycling examples, assignments and projects. This type of approach does not allow skills acquisition, critical thinking and creativity needed in a challenging multi-disciplinary course like engineering. Notably, some enhancements have been observed following the diffusion of ICT into the teaching, and learning process and this creates some sort of modification on the process. Moreover, there are quite a number of methods that could be used/or integrated in to the teaching method as highlighted in [11]. These methods are expected to improve students' learning.

This work therefore, carried out a descriptive survey on the effectiveness and usefulness of these methods. All the 32 teaching and learning methods highlighted in [11] were used and put forward to 500 engineering students in a form of questioner. Three main categories were identified, these are: form of learning, mode of learning and mode of questions. In the learning category, $63 \%$ of the respondent, believed that visual is the best form of learning and $69 \%$ preferred active teaching as the best mode of learning. While, $72 \%$ said question that requires creativity but fair is the preferred mode of asking questions. Furthermore, the paper investigates lecturers' teaching style and how it affects learning process. It is worthy to note that each teaching method has its own characteristics, merits and demerits .In addition, peculiarities of most Nigeria Engineering class rooms requires teachers to be competent and convenient in handling such extreme situations. Therefore, 100 lectures in Engineering and 
related fields were also administered with the questioner with the aim to examine the convenience of the lectures' teaching style considering the infrastructure constraints bevelling the system. Among the respondent, 74\% identified that talk-chalk method without practical is the most convenient. This is as a result of lack of necessary infrastructure to do the needful. Other factors identified hindering adoption of other better methods was excessive work load, inadequate and up-to-date non-functional practical facilities and high number of students in the class. Similarly, Felder and Silverman in[23] examined different learning methods useful to engineering education and the author concluded that the engineering learning style is not fit for purpose. This is because the learning styles used that is acceptable to the majority of engineering students and the adopted teaching styles of most engineering teachers are not compatible. These findings indicate agreement with our exploratory survey. The authors in [12] further argued that most engineering students are visual, sensing, inductive, active, and creative whereas the teaching methods used are mostly passive, auditory, abstract, deductive and sequential. Thus, leading to incompatibility between the teaching and the learning process, and hence, resulting to poor performance among engineering students,

\subsection{Engineering Education Curriculum}

Curriculum is one of the most important component of implementing any education policy as it describes the syllabus, teaching methods employed and ultimately, it would determine the learning experience. Engineering curriculum is expected to be dynamic to reflect the change in emerging engineering and societal problems. Curriculum is a reflection and a product of the society and can contribute to changing the society [24]. Therefore, it is important in the process of the curriculum development and education process to reflect labour market issues. Furthermore, for sustainable development, engineering curriculum has to be innovative project-based and has to be linked with our local industries. The knowledge passed through the modern day engineering curriculum must be flexible, dynamic and encompass a broad knowledge within a specialised filed of knowledge. The traditional mode of engineering curriculum cannot provide these and the present day work environment requires specialised individual. Therefore, there is a need to have different tracks or specialisation within the same subject area. This method is been adopted in the United Kingdom where the students spend three years obtaining a specialised degree while the fourth year is being spent in the industry. The program is designed in such a way that critical thinking, independent problem solving and creativity are rewarded and encouraged. Depending and relying on one's leads to creativity and problem-solving skills. These skills are important for independent learners to develop and possess while overcoming challenges that are associated with modern day engineering. Therefore, the curriculum must allow for attitudes that can bring out the skills and knowledge gained. Attitude is also important because team work is an essential feature in solving engineering challenges. The curriculum must encourage more team work because the reality is that most projects in the field of engineering today and in the future require team work from diverse range of knowledge culture, social and religious backgrounds.

Unfortunately, lot of names have been associated with the engineering education in Nigeria. The static nature of Nigerian engineering curriculum makes[25] to described it as obsolete. This is because there is a huge gap between the general education knowledge provided by the universities and technical skills required by the industries. As such, the graduates are not meeting the needs of the labour markets, thus, necessitating the need for retraining programs by the employers. The current engineering education is also described as out of touch especially with what is going on in the industry [10]. This also defeats the aim of the $21^{\text {st }}$-century engineering education which is supposed to provide knowledge, skills and attitude [26]. Some authors also describe the present day engineering training as that of the era of the parents of the present day engineers [27].

Although, individual efforts towards realising dynamic engineering curriculum are acknowledged due to recent growth in number of lecturers acquiring higher degrees from abroad. Also, with the recent improvements on internet access in the Nigerian Universities, have provided access to a wider range of information and educational resources, this has further broaden the need and call for a review of the system. Despite all these, there is no significant improvement in terms of the curriculum. Based on the findings from the exploratory survey conducted, $94 \%$ of the lecturers who have obtained postgraduate degree outside Nigeria and realised the need for improved curriculum, attended a conference or seminar where improved engineering curriculum is encouraged said they cannot implement what they have learnt. This is because of the lack of the necessary infrastructure and work load. Therefore, equipment and better infrastructure is an important aspect of the improved curriculum.

Furthermore, It was also discovered that human attitude towards marking the change must also be encouraged. Conferences are expected to expose 
lecturers to latest discovery and stimulate discussions among teachers and students about the latest discovery in modern engineering world. Increase in conference attendance has not been reflected significantly in our lecture notes. This conclusion was based on the responses obtained from 615 engineering students from the University of Ilorin and Kwara state University, Nigeria, among which $92 \%$ affirmed that none of their lectures mentioned any new invention or discovery as a result of attending a conference during any of their lectures. The problem of changing existing curriculum is not only peculiar to Nigeria but across the globe to include countries like USA, UK and Australia [8, 28]. This is because the global problem with engineering education has to do with the challenges of

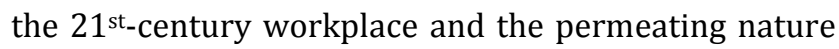
of product and services provided by engineers. Therefore the lack of willingness to adopt changes in engineering curriculum as the field of engineering is changing is a global problem [28]. A general reason for refusing changes in engineering education has to do with the fact that this field is changing very fast and before a curriculum change can be made, some more advance changes are already recorded on the field. However, changing this attitude must be encouraged in Nigeria as it is been presently done around the globe. This is as a result of the review processes that are recently in place.

\subsection{Equipment and Infrastructure}

Apart from the global problems, engineering education in Nigeria is facing some peculiar problems like lack of equipment and infrastructure. Most engineering faculties in Nigeria complain about the lack or inadequate availability of necessary basic equipment and Infrastructure. This is because of inadequate funding to our universities. $95 \%$ and $90 \%$ of students and lecturers respectively who filled the questioner complained about the level of available equipment and infrastructure in our engineering departments. In fact $98 \%$ of the respondents picked lack of equipment and necessary infrastructure like classrooms and teaching aid equipment and the major barrier to teaching and learning of engineering in Nigeria

Long Term Effects of the challenges of the Nigerian Engineering Education System

The challenges being faced by engineering education in Nigeria is having some negative impacts. Fig 1 shows the number of undergraduate engineering departments in thirteen of Nigerian universities. This includes 4 universities of technology, and other universities picked based on random sampling. The table compares the number of departments per faculty of engineering in each university that was fully accredited between the years 2005- 2009 and between the years 20142016. The table further compares by finding the percentage of the ones still enjoying full accreditation during the latter (2014-2016) years compared to the former (2005-2009). The figures are as published by the National Universities Commission, (NUC) Nigeria in [29].

It can be seen from Fig 1 that apart from Ahmadu Bello University (ABU) Zaria, that maintained a $100 \%$ record, none of the other universities is having a full accreditation for all departments there were fully accredited anytime between 2005 and 2009 in the years 2014 to 2016. It can, therefore, be seen that a significant number of the existing departments in engineering faculties in the Nigerian university cannot even meet up with the expected standard as set out by the NUC. In fact, Universities of Port Harcourt and Benin lost all accreditation for the entire faculty of engineering. This shows that a significant number of engineering departments in Nigerian universities are not presently not fit for purpose. Therefore, we can conclude that one of the main effects of the challenges being faced is that our engineering departments are no longer fit for purpose.

However, some would argue that despite these challenges, Nigerians, especially, those studying for a postgraduate degree outside the country after obtaining their first degree within the country are still performing well. Although, our findings in shows a decline in the last few years as seen later. This is because of the limited practical work which are not often graded in the past, but, are usually graded in most universities especially in the UK. According to the records obtained from 12 universities in the UK. Three of these universities are among the top ten universities in the UK according to the 2015 ranking of the times higher education. In each of these universities, on the average, 2 Nigerians graduated each year with a distinction in master's degree in engineering from the year 2000 to 2015. These universities are however producing an average of 9 students with a distinction in the same year and with the same degree. The findings show that at the moment only a tiny minority of Nigerians studying for a post graduate degree in engineering outside Nigeria failed to get the desired degree, but the trend is on the increase. This can also be seen from Figure 3whichshows the percentage of Nigerians who failed in their postgraduate degree in Engineering in the universities that responded to our request in the United Kingdom.

Fig 2 shows that from 2000/2001 academic session to date less than $3 \%$ of Nigerians admitted to study a postgraduate masters degree in Engineering in the UK failed to graduate. 


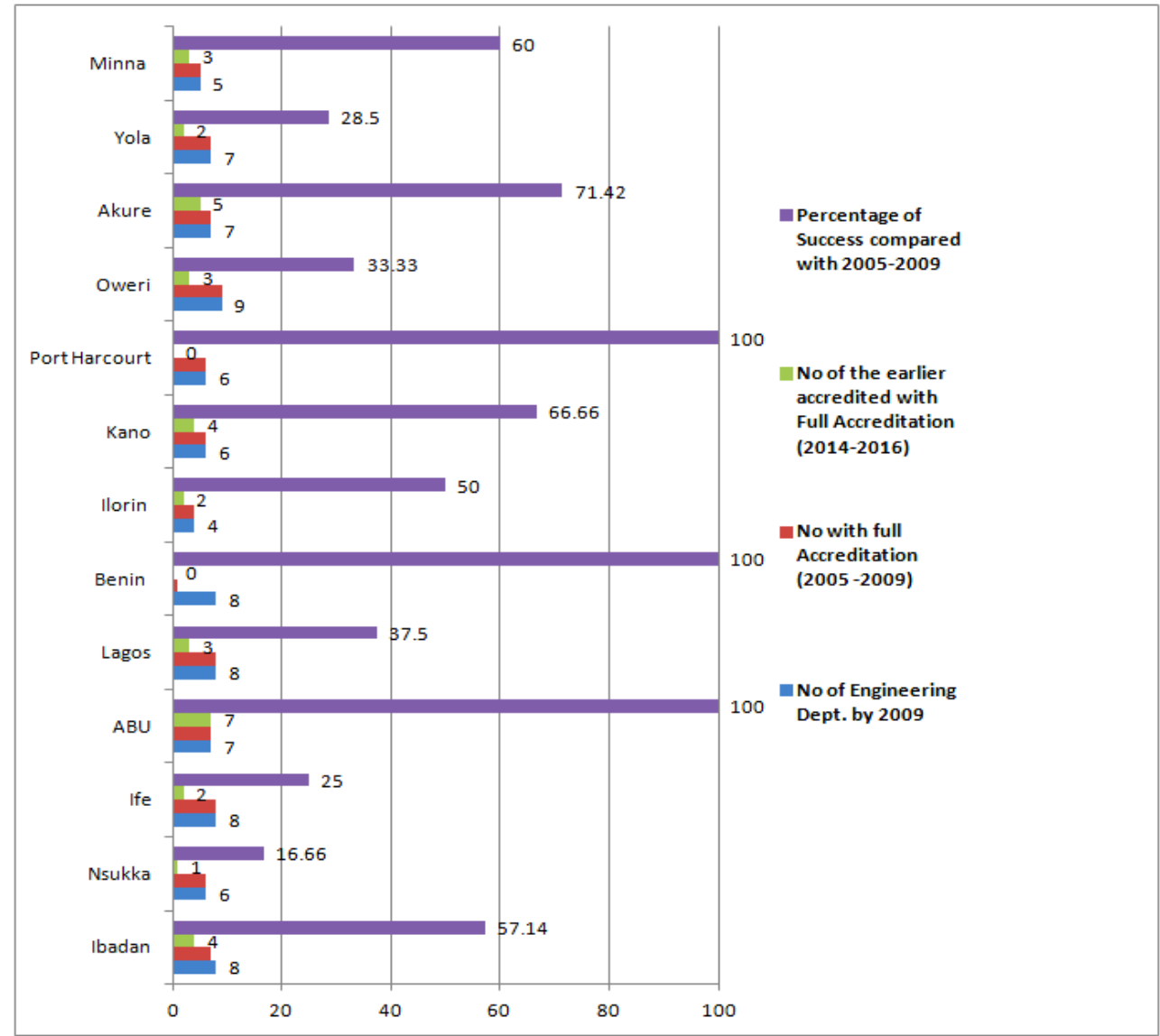

Figure 1: Number of Accredited Departments in Engineering Faculties in some Nigerian Universities [10]

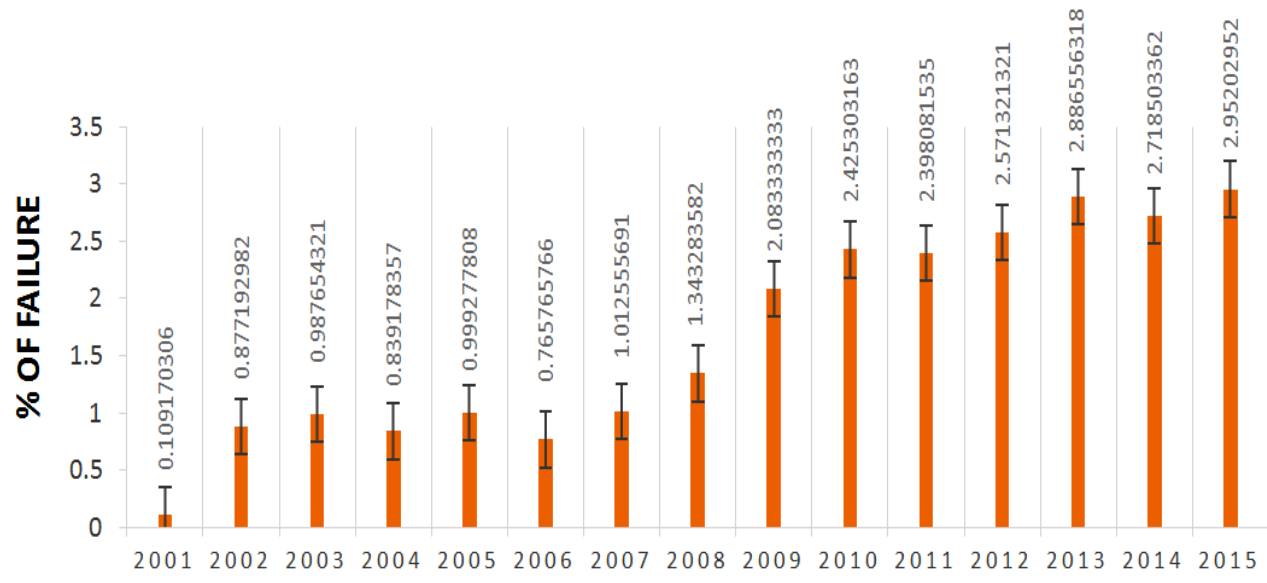

YEAR

Figure 2: Percentage of Failure of Nigerian Engineering Post Graduate Engineering students

This shows that the challenges are actually having an effect on Nigerian students across the globe. Figure 2also shows that from the year 2007, there are more than $2 \%$ of Nigerians failed compared to the years before 2007. This might be an indication that if this trend continues, then there is a likelihood that more Nigerians studying in the UK would not be able to cope with the new approach to engineering education.

\section{THE OUTLOOK OF ENGINEERING EDUCATION IN NIGERIA}

At the moment, some of the Nigerian engineering students might be recording some success as stated in the previous section. However, the path of engineering education outside Nigeria is changing. This is because there is the new realisation that engineering education should be tailored towards the need of the society [26]. For example, China needs a larger number of engineers for its fast growing economy whereas engineers that 
can outsource, coordinate the supply chain is needed in the United States [30].

The immediate future of engineering education in other countries is also changing; there is a movement towards a more practical based learning approach, teamwork development, open-ended problem solving, experimental learning and active research. Most of these can't be found in the education system in Nigeria. For example, problem-based learning that was proposed by [31,32] is already being implemented in the UK. In the UK, students are now allowed to construct their knowledge and confront their own misconceptions. The system also emphasised more on the strategic importance and impact of research and technological development towards the society at large.It is worth pointing out that $97 \%$ of our respondents who studied in a developed western countries in the last 3 years believe that they went through more practical based learning model than they envisaged before the commencement of the program. In fact, $95 \%$ of our respondents who studied for a $\mathrm{PhD}$ degree believed that the major problem they faced during their studies is the lack of practical and programming skills.

Furthermore, as part of the changes around the globe, the use of Conceive-Design-Implement-Operate (CIDO) which is aimed at helping students to master deep working knowledge of technical fundamental, create and operate new product and understand of the importance and strategic impact of technological and research development is being implemented in the US[33]. If the future need of engineering students in Nigeria is not addressed, then there is a likelihood of a wider gap between the Nigeria engineering education and that of the rest of the world making it more difficult if future for students going for further education outside Nigeria. [34, 35].

\section{PROPOSED SOLUTIONS}

Engineering students must be able to learn new skills discretely and fast to meet up with the ever changing requirements of the engineering field. Majority of the engineering departments in Nigerian university are not customer-focused as a result of either lack of funds or the fact that the number seeking admission year in year out far exceeds the number of places available. A clear understanding of the need of the customer, the students (who are the most important customer), their parents, the society and the industry that would eventually employ theses student would go a long way in making sure that some level of quality is achieved.

To meet up with the demand of the industry and to be able to continue to compete favourably around the world, a number of changes have to be implemented to improve the quality of engineering education in
Nigeria.[36] proposed substantial changes in engineering education to include a change in attitude, philosophy, performance, leadership skills, combination of both technical and non-technical components. In addition to these, the traditional teaching method that assumes that knowledge can be gained using the transmittal approach while passively listening to lectures without adequate training must also be re-examined. Consequently, some major changes that need immediate attention and how to go about these changes are discussed below:

\subsection{Use of innovative approaches to teaching and learning}

The use of innovative approaches to teaching and learning is very essential. For quality assurance test, this paper examined students' satisfaction level in terms of teaching methods and general learning. Results indicate that $96 \%$ of the respondents who have studied in the university abroad are satisfied with the quality of engineering education they received or obtained. However, only $14 \%$ of the respondents were satisfied with the quality of engineering education in Nigeria. In addition , $100 \%$ of the respondents agreed that the staff outside Nigeria who are always using teaching aids are better at explaining things, provide better concentration, participation in class and were able to retain what is being taught much longer compared to the traditional method of teaching used in the Nigeria teachers. $100 \%$ of the respondents also confirmed that the fact that teaching materials are available online before and after lectures makes learning easier. This indicates that education is global, and lecturers should be encouraged to making their notes available online. The use of technological teaching aids is long overdue. This has to be given proper attention by both the management and staff of our universities. Some lecturers are not taking adequate advantage of the little aids such as projectors and electronics boards presently available. This may be as a result of lack of knowledge about the usage of these equipment. This was also confirmed in our questioner administered to staff of the University of Ilorin and Kwara state university, where only $25 \%$ of the lecturers are confirmed using the electronics boards installed five years ago in one of the lecture rooms. However 54\% of the respondents who are not using it said they are not using it as a result of unreliability of electricity while $37 \%$ are not using it because they do not understand how to use it. Therefore adequate retraining program must also be carried out to make sure that this can be put to proper use. 


\subsection{Continuous Modification in the Curriculum of Engineering Education}

To meet up with the future demand, there has to be machinery in place to accommodate the rapid technological changes that are now being experienced. Any curriculum that would meet the need of the industrial practice has to change continuously. New technology is developing at a rate where if care is not taken before a change has been implemented the technology would have changed. The problem associated with these changes can be solved by providing long life learning, where essential skills are the ones taught .Knowledge skills and attitude must also be emphasised. Teamwork must be encouraged because the processes and systems that engineers would have to conceive, create and operate are quite complex. Hence it is important that engineers must learn to solve problems in teams. Furthermore, the test to students must be challenging but fair. According to [8], Knowledge is the database of an engineer, skills are the tools used to manipulate the knowledge to meet a goal dictated or strongly influence by attitude.

Presently, there is a growing acceptance of online degrees from foreign universities. $89 \%$ of the undergraduate respondents to our questioner said they would be happy to have an online degree from a university outside Nigeria if going forward for a masters degree as an alternative to travelling outside Nigeria. The reason provided is that they believe they would be getting better knowledge from the online degrees than attending a conventional university in Nigeria. This is a big sign that conventional universities in Nigeria must continue to evolve and improve upon the content. With technological advancement, the world is now a global village, and giving the universal nature of education, if care is not taking, with the way technology is advancing, there is a likelihood that in the near future technical course like engineering would be taught online to include access to practicals and this might have some negative impacts on the enrolments of student in our universities. This practical might be designed using software to simulate the real environment.

\subsection{Teaching what is necessary in the real world}

Engineering Education was described as a three-legged stool relying on science mathematics and technique[37]. Just as a stool cannot stand on two legs, adopting a proper technique is as important as the other two. The technique needed in the field of engineering cannot be fully taught within the four walls of the classroom. There is a need for interaction and reinforcement of the essential fundamentals that an engineer would need when on the field. Engineering education must provide increased practical experience.
This helps the students' ability to learn the abstract and theory that forms much of the engineering fundamentals. It also helps their ability to realise the applicability and practical usefulness of a good theory. A solution to this would be emphasising more on the fundamentals of science with integrated knowledge while more time would be spent focusing on the real world. According to a research which studied successful young engineers across the field of engineering [38, 39], the study showed that success in the field of engineering lies in the combination of generic skills with technical capabilities with emotional intelligence and focused thinking. The research also showed that less emphasis should be on assessment of predictable skills as more of technical expertise should be examined. This means that lecturers should adopt the use of application based test such that the real world capability is tested. Furthermore, [40] emphasised that the real world must be taught by teaching majorly the basics, problem-solving skills, engineering ethics, and the connection between technology and the society while reducing the number of years spent in the class room. Teaching what is necessary in the real world requires more equipment and infrastructures. Therefore, government and the management of our universities must provide more in terms of equipment and infrastructure.

\subsection{Degree Specialisation and an Option to Spend a Full Year in the industry.}

The reality facing engineering education today is significantly different from that of the past, and the future would be distinct from that of today. To meet the future need of engineering education, significant changes are required. The need of today is different, and the relevance and direction of some of the modules or departments in some faculty of engineering have to be questioned. For example, up until the early 90 s, an electrical engineering graduate in Nigeria is expected to work for an electrical company or somewhere similar. However, the reality of today is that electrical engineers are now computer engineers, telecommunication engineers and even biomedical engineers where different knowledge of biology, telecommunications computer language and programming are all essential to being able to perform well. Therefore, the present five-year engineering learning structure in the university without specialisation would not meet the need of future engineers [5]. There is a need to breakdown the areas of specialisation and stop the idea of generalisation. In addition to this, the number of years spent in the classroom has to be reduced and allow for a full year to be spent as part of the degree in the industry. This method has long been adopted in countries like the 
United Kingdom, where students spend three or four years for a specialised degree in engineering. Each of the years spent on the degree include a group project with a substantial individual project in the final year. In addition to this, in the $3^{\text {rd }}$ and $4^{\text {th }}$ year students have the flexibility in the choice of specialisation based on the student's interest. Furthermore, there is an option to spend a full year in the industry. Depending on the option a student picks, the degree awarded is different. For example, a student who has spent 3 years is awarded a B.Eng, a student who is spending 4 years is awarded an M.Eng, and a student can also have an M.Eng degree (with a full year in the industry). This gives the students and the employers some level of flexibility and a good understanding of the knowledge to expect from the student depending on the degree.

Methods of implementing the proposed changes.

The following are the proposed methods that can be used while implementing the needed change in engineering education in Nigeria.

\section{A. Application of Total Quality Management (TQM)}

TQM is a continuous statistical quality control or management method used to enhance the quality and productivity of a business organisation. It must be supported by all involved extending back and forward to include all departments and employees. It is usually applied by companies that provide goods and services. The use of this method would allow for us to properly scrutinise the engineering education in Nigeria and propose a holistic review. This method has been applied in various universities around the world such as in the USA India and UK. [41, 42] They applied four major principles

Biased and focused towards customer satisfaction Customers are the ones who define their satisfaction Improvement is a continuous process

The greatest assets of the organization are the people However [41] proposed some things that must be in place before TQM can be implemented such that top leadership of the university must be the driving force, commitment on the part of all, customer-focus, continuous evaluation of the process, availability of resources, training and retraining of management, staff and students, empowering of employees, effective communication, long term strategy and planning among others. The use of the method allows for the efficient transition of students from the university environments into the work environment, and it would provide better performance since university education is meant to prepare students for the wider engineering industry just like a company providing goods and services to the people.

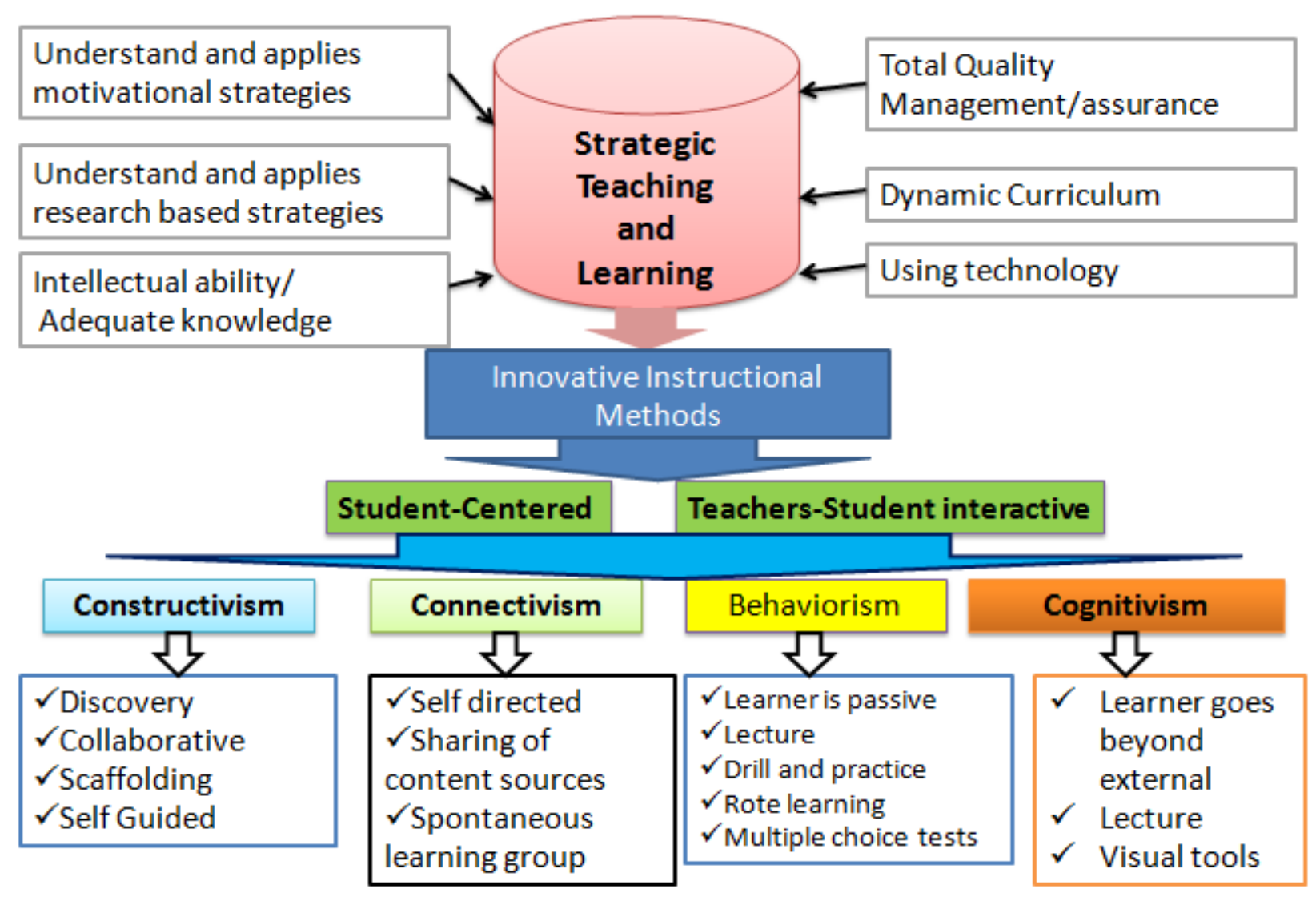

Figure 3. Strategic Teaching and Learning Approach Towards Sustainable Engineering Education 


\section{B. Convert Engineering Education into a manufacturing process.}

The manufacturing process involves planning, designing, analysing and applying managerial processes so that quality products can be produced at a competitive cost. As advocated in [8] engineering education can be broken down into a manufacturing process such that benchmarking, quality assurance and other industrial quality control can be used to examine its performance. Another important element of a manufacturing process is feedback. Feedback from the industry on how well the universities are performing would help to improve the quality of engineering graduates. One major element of a manufacturing process is also the prevention of bad input into the system. This can also be applied to engineering education in Nigeria by making sure that those admitted into the engineering departments are ready for the challenges ahead.

\section{CONCLUSIONS}

This paper examined engineering education in Nigeria with its challenges. The paper discussed in details three main challenges that have to do with teaching and learning which the main focus of this paper. The paper showed a decline the number of accredited engineering departments in Nigeria Universities and increases in the number of Nigerian engineering student who failed to get a degree abroad. This paper advocates that the engineering education should be more customer focused and focus on the real world. It also pointed out the need to examine alternative teaching and learning methods. This is because the traditional teaching method in Nigeria will probably not be adequate to equip the future engineering graduates of the necessary attitude and skills that would be required to achieve success both at the post-graduate studies level and for practice in the industry.

\section{REFERENCES}

[1] C. L. (, 26/06/2016). Data show Nigerians the most educated in the U.S. Available: http://www.chron.com/news/article/Data-showNigerians-the-most-educated-in-the-U-S1600808.php,2008.

[2] V. Uwaifo and P. Uddin, "Transition from the 6-3-3-4 to the 9-3-4 system of education in Nigeria: An assessment of its implementation on technology subjects," Studies on Home Community Science, vol. 3, pp. 81-86, 2009.

[3] J. E. Dunford and P. R. Sharp, The education system in England and Wales: Longman Publishing Group, 1990.
[4] A. Corsi-Bunker, "Guide to the education system in the United States," University of Minnesota, nd Web, vol. 23, 2015.

[5] T. Moja, "Nigeria education sector analysis: An analytical synthesis of performance and main issues," World Bank Report, 2000.

[3] G. Ojiakor, "University Engineering Education and Training In Nigeria: Development, Weaknesses And Improvements," Nigerian Journal of Technology, vol. 10 , pp. 46-56.

[6] T. Moja, "Nigeria education sector analysis: An analytical synthesis of performance and main issues," World Bank Report, 2000.

[7] A. Idris and M. Rajuddin, "The trend of engineering education in Nigerian tertiary institutions of learning towards achieving technological development," Procedia-Social and Behavioral Sciences, vol. 56, pp. 730-736, 2012.

[8] M. Jaraiedi and D. Ritz, "Total quality management applied to engineering education," Quality Assurance in Education, vol. 2, pp. 32-40, 1994.

[9] H. A. A. Ajimotokan, K. R. Adebiyi,K. A. Dainkeh, A. and Oloyede, A. A. , " Engineering Education and Sustainable Development in Nigeria ".Journal of Research Information in Civil Engineering, vol. 7, pp. $1-6,2010$.

[10] O. F. Kofoworola, "Engineering education in Nigeria: present learning systems and challenges for the future," Australasian J. Eng. Edu, vol. 1, pp. 2-7, 2003.

[11] A. Akintola, G. Aderounmu, and O. Owolarafe, "Problems of engineering education and training in developing countries: Nigeria as a case study," European journal of engineering education, vol. 27, pp. 393-400, 2002.

[12] D. Teferra and P. G. Altbachl, "African higher education: Challenges for the 21st century," Higher education, vol. 47, pp. 21-50, 2004.

[13] C. O. Taiwo, The Nigerian education system: past, present, and future: Ikeja, Nigeria: T. Nelson, 1980.

[14] C. C. Zuofa and C. N. Olori, "Appraising Adult Teaching Methods in Nigeria: Analysis of the Effect of Some Teaching Methods on Adult Learners," American Journal of Educational Research, vol. 3, pp. 1133-1137, 2015.

[15] A. Tebabal and G. Kahssay, "The effects of studentcentered approach in improving students' graphical interpretation skills and conceptual understanding of kinematical motion, " Latin-American Journal of Physics Education, vol. 5, p. 9, 2011.

[16] S. Brookfield, Understanding and facilitating adult learning. A comprehensive analysis of principles and effective practices: McGraw-Hill Education (UK), 1986.

[17] S. Kerka, "Adult Learner Retention Revisited. ERIC Digest No. 166," 1995. 
[18] M. S. Knowles, The modern practice of adult education vol. 41: New York Association Press New York, 1970.

[19] H. C. Sitler, "The spaced lecture," College Teaching, vol. 45, pp. 108-110, 1997.

[20] G. Adekola, "Methods and materials utilisation in adult and non-formal education" Ibadan: Gabesther, 2008.

[21] I. Nzeneri, "Handbook on adult education: Principles and practices, "Uyo-Nigeria: Abigab Associates Ltd, 2008.

[22] C. Zuofa, "Modern perspective on adult education in Nigeria," Port Harcourt: Pre-Joe Publisher. A division of Pre-Joe Ventures, 2001.

[23] R. M. Felder and L. K. Silverman, "Learning and teaching styles in engineering education," Engineering education, vol. 78, pp. 674-681, 1988.

[24] F. Paykoç, B. Mengi, P. O. Kamay, P. Önkol, B. Özgür, O. Pilli, et al., "What are the major curriculum issues? The use of mind mapping as a brainstorming exercise," in Proceedings of the First International Conference on Concept Mapping, pp. 457-467, 2004.

[25] S. T. Adedokun, "What are they made up of today? A look at engineering education in developing nations with Nigeria as a case study," Journal of Emerging Trends in Engineering and Applied Sciences, vol. 2, pp. 308-313, 2011.

[26] A. Rugarcia, R. M. Felder, D. R. Woods, and J. E. Stice, "The future of engineering education I. A vision for a new century," Chemical Engineering Education, vol. 34, pp. 16-25, 2000.

[27] W. A. Wulf and G. M. Fisher, "A makeover for engineering education," Issues in Science and Technology, vol. 18, pp. 35-39, 2002.

[28] R. Graham, "Achieving excellence in engineering education: the ingredients of successful change," The Royal Academy of Engineering, vol. 3, 2012.

[29] N. U. Commission.. Accreditation result 1990-2016. Available: results/,2016

[30] J. Levy, "Engineering education in the United Kingdom: standards, quality assurance and accreditation," International Journal of Engineering Education, vol. 16, pp. 136-145, 2000.

[31] A. Rugarcia, R. M. Felder, D. R. Woods, and J. E. Stice, "The future of engineering education I. A vision for a new century," Chemical Engineering Education, vol. 34, pp. 16-25, 2000.

[32] J. B. X. Zhang, "Comparative Study on Engineering Education in China and USA," B. sc, Worchester Polytecnic Institute, Worchester Polytecnic Institute.
[33] W. Hung, D. H. Jonassen, and R. Liu, "Problem-based learning," Handbook of research on educational communications and technology, vol. 3, pp. 485-506, 2008.

[34] H. S. Barrows, "A taxonomy of problem-based learning methods," Medical education, vol. 20, pp. 481-486, 1986.

[35] G. Gustafsson, D. J. Newman, S. Stafström, and H. P. Wallin, "First-year introductory courses as a means to develop conceive-design-implement-operate skills in engineering education programmes," SEFIrenze 2002, Florence, Italy, 8-11 September 2002, 2002.

[36] L. Odia and S. Omofonmwan, "Educational system in Nigeria problems and prospects," Journal of Social Sciences, vol. 14, pp. 81-86, 2007.

[37] W. Saint, T. A. Hartnett, and E. Strassner, "Higher education in Nigeria: A status report," Higher education policy, vol. 16, pp. 259-281, 2003.

[38] D. Teferra and P. G. Altbachl, "African higher education: Challenges for the 21st century," Higher education, vol. 47, pp. 21-50, 2004.

[39] C. 0. Taiwo, The Nigerian education system: past, present, and future: Ikeja, Nigeria: T. Nelson, 1980.

[40] J. Bordogna, E. Fromm, and E. W. Ernst, "Engineering education: Innovation through integration," Journal of Engineering Education, vol. 82, pp. 3-8, 1993.

[41] F. Maillardet, "What outcome is engineering education trying to achieve," Effective Learning and Teaching in Engineering, pp. 27-35, 2004.

[42] G. Scott and K. W. Yates, "Using successful graduates to improve the quality of undergraduate engineering programmes," European Journal of Engineering education, vol. 27, pp. 363-378, 2002.

[43] G. Scott, E. Chang, and L. Grebennikov, "Using successful graduates to improve the quality of undergraduate nursing programs," Journal of Teaching and Learning for Graduate Employability, vol. 1, pp. 26-44, 2010.

[44] R. M. Felder, D. R. Woods, J. E. Stice, and A. Rugarcia, "The future of engineering education II. Teaching methods that work," Chemical Engineering Education, vol. 34, pp. 26-39, 2000.

[45] E. Staiou, "Total quality management in engineering education," in Proceedings of the 3rd WSEAS/IASME International Conference on Engineering Education, Vouliagmeni, Greece, pp. 125-130, 2006.

[46] E. Crawley, J. Malmqvist, S. Ostlund, and D. Brodeur, "Rethinking engineering education," The CDIO Approach, p. 302, 2007. 